\title{
The Nation-State, Globalisation and the Modern Institution of the University
}

\author{
Marek Kwiek
}

Thinking about the 'identity crisis' of the modern institution of the university, I was wondering about the following most general questions: does the current passage to late modernity and to the information age, the decline of the role of the nation-state and the increasing power of processes of globalisation mean the inevitability of the radical reformulation of the social mission and tasks of the institution of the university? Does the university (in North America and Central Europe alike) come through the transitory crisis of public trust and of its founding values or through the dramatic crisis of its own identity in a radically new global order? Is it so that in the face of globalisation and its social practices the process of the 'corporatization' of the university and the account of its activities in terms of business rather than education are irresistible? Is the response to the decreasing public trust in and decreasing financial support of higher education generally on the part of the state to be found in new ideas (by reformulating once again the philosophical foundations of the modern university) or in its new organisation (by following the explicit recommendations provided by such supranational organisations as the OECD, the World Bank, or UNESCO)? Surprisingly enough, these questions are of equal significance to North America and to a Central and Eastern Europe experiencing vast social and economic transformation. In both parts of the world the most common reflection upon the future functioning of higher education is the following: 'things will never be the same'.

In the face of globalisation, on the one hand, and of a cultural passage to late modernity (or postmodernity) on the other, the issue of the decline of the nation-state is widely discussed by sociologists, political scientists, philosophers, economists, historians and representatives of many other academic disciplines. The nation-state as a
\end{abstract}


product of modernity is in question: in this context, the crucial oppositions discussed today are 'international integration' versus 'national disintegration', 'globalisation' versus 'domestic social stability', 'market' versus 'society' and 'state', 'economy' versus 'politics' and 'democracy', 'transnationals' (TNCs) versus 'state governments', etc. To question the nation-state today is to ask questions about the future of capitalism, democracy and the welfare state, as well as questions about political freedom, sovereignty, citizenship and the future of the still binding, modern social contract according to which a clear link existed between social security, political freedom and democracy.

The question of the decline of the nation-state is parallel, in my account, to questions about the human and social consequences of globalisation, the decline of modernity, the end of history, the 'death of the intellectual' and the decline of the modern institution of the university. These questions form an aggregate of problems with which modern thought seems unable to cope. New cultural, social, political and economic surroundings brought about by globalisation seem to require a totally new language, which we, surely enough, do not have at our disposal right now. So we keep using old measures and vocabularies to describe phenomena of the new world (of 'new global order', or 'new global disorder', some commentators argue). Generally speaking, there seems to be common agreement that globalisation as a wide set of social and economic practices introduces to our social world a brand new quality: 'a sense of rupture with the past pervades the public consciousness of our time', as Martin Albrow (1996: 1) says, and Ulrich Beck in What Is Globalization? describes the passage from the 'first' (national) to the 'second' (global) modernity in sociological terms as 'a fundamental transformation, a paradigm shift, a departure into the unknown world of globality' (Beck 2000: 125). We are certainly justified in saying that what we are witnessing right now is 'the end of the world as we know it' (see Waters 1995: 158ff).

The question about the role the nation-state plays in contemporary world and about its future in the face of globalisation is a crucial one. In this paper I will attempt to show that the identity crisis of the modern institution of the university is strictly connected with the decline (or reformulation of the role) of the nation-state in the global age, for globalisation on the one hand, and the decline of the social, cultural and political project of modernity on the other, affects both elements of the power/knowledge relation: both the knowledge produced by the modern university and the power of the modern nation-state are 
reconfigured. Björn Wittrock in his historical essay about the modern university wrote that 'universities form part and parcel of the very same process which manifests itself in the emergence of an industrial economic order and the nation-state as the most typical and most important form of political organisation' (Wittrock 1993: 305, emphasis mine). Evidently, the significance of the transformations of universities in the global age would not be fully captured outside of the context of changes that the economic order and the nation-state are currently undergoing.

\section{II}

Let me start with a bit of history of the institution. The university in the form we are familiar with - the modern university - derives from the intellectual work of German philosophers: from Kant and Fichte to Schleiermacher and Wilhelm von Humboldt (see Kant 1970, 1979; Schelling 1963; Ferry and Renaut 1979). Being a modern institution, it is relatively new and was born together with the rise in national aspirations and the rise in the significance of nation-states in the nineteenth century. A tacit deal made between power and knowledge on the one hand provided scholars with unprecedented institutional possibilities and, on the other, obliged them to support national culture and to help with constituting national subjects: citizens of nationstates. The alliance between modern knowledge and modern power gave rise to the foundations of the modern institution of the university. European as well as American universities were either founded or at least transformed ${ }^{1}$ on the basis of the project written in 1808 by Wilhelm von Humboldt for the University of Berlin (see Lucas 1996; Humboldt 1979).

The place, social function and role of the university as one of the most significant institutions of modernity were clearly outlined. But currently, when the project of modernity is undergoing radical transformation (toward late-modernity, or even postmodernity) ${ }^{2}$, it is no longer known what the exact place of the university in society is, for the society itself gets changed. As the late Bill Readings observed in his breath-taking reflections about the 'posthistorical university':

... the wider social role of the University as an institution is now up for grabs. It is no longer clear what the place of the University within society nor what the exact nature of that society is. (Readings 1996: 2) $)^{3}$ 
The uncertainty about the future location of the institution of the university in culture grows together with structural changes occurring in economy, culture, and politics: it is often the case that small nationstates are no longer equal partners for big capital (see Holton 1998: 81-107; Barnet \& Cavanagh 1997; Friedman 1999). The nation-state as a political and cultural project - but unfortunately not particular nationalisms - seems to be declining in the surroundings determined by globalisation, which in itself is a topic of a heated debate in political sciences (these processes can be clearly seen both in the countries from the European Union, in Central and Eastern European countries entering it, as well as in the countries of both Americas). ${ }^{4}$ As Dani Rodrik, a political economist, put it recently:

we need to be upfront about the irreversibility of the many changes that have occurred in the global economy. ... In short, the genie cannot be stuffed back into the bottle, even if it were desirable to do so. We will need more imaginative and more subtle responses. (Rodrik 1997: 9)

I have to agree with Ulrich Beck when he claims that one constant feature of globalisation is the overturning of the central premise of modernity, 'the idea that we live and act in the self-enclosed spaces of national states and their respective national societies' (Beck 2000: 20). Capital, goods, technologies, information and people cross frontiers in ways that were unimaginable before: thus globalisation is 'the time/space compression' (Bauman), 'the overcoming of distance' (Beck), la fin de la geographie (Paul Virilio).

One could risk the following statement: in the age of globalisation, national identity ceases to be the most important social glue and therefore its production, cultivation and inculcation - that is, the ideals that stood behind the modern project of the university - cease to be crucial social tasks. (And let us remember here what Humboldt wrote in his foundational text about the institution of the university, 'Über die innere und äußere Organisation der höheren wissenschaftlichen Anstalten in Berlin': what is at stake in reorganising the university is 'an essential matter of national Bildung' [Humboldt 1979: 321; see Richardson 1984]).

The traditional, modern social mission of the university as an institutional arm of the nation-state has been unexpectedly questioned after two centuries of domination in culture. The university as we know it - the modern university - is in a delicate and complicated position at the moment: the great cultural project of modernity that 
has located the university in the very centre of culture - in partnership with the institution of the nation-state - may be gradually outliving itself. After two hundred years - merely two hundred years! - it is no longer known to what, if any, great regulatory idea the university in search of its present raison d'être might refer. ${ }^{5}$ In its modern beginnings, as Bill Readings shows, in Kant in The Conflict of the Faculties, the regulatory idea in question was Enlightenment reason; ${ }^{6}$ then, in Schleiermacher and Humboldt, the idea was culture in an active sense of Bildung, cultivating oneself as a subject of the nation-state (see Richardson 1984). Should we thus today, as Alain Renaut puts it, oublier Berlin (see Renaut 1995: 138; Allègre 1993)?

The university seems to be no longer capable of maintaining its modern role as a cultural institution closely connected with the nation-state of Enlightenment and post-Enlightenment Europe. In the globalising world of today references made to national culture as the raison d'être of the university sound less and less convincing, especially considering the fact that the state itself, the partner and the other side of the agreement, itself undergoing transformation, disregards - perhaps out of necessity? - its past, that is, its modern obligations with respect to the university.

All the (academic) world is perfectly aware of the fact that there will probably never be a return to the level of financing universities (both in the natural sciences and the humanities) from the Cold War era and a tough (inter)national competitive epoch (see Hovey 1999). The United Europe, for instance, does not seem to need narrowly national universities, for teaching and research are to aim at unification rather than isolation of particular national traditions. References to reason or culture are no longer persuasive in society. These ideas are no longer politically (and economically) resonant because the global configuration of politics and economy has changed: within the new global configuration, economy is increasingly less dependent on politics. It is worthwhile to think again about the thesis suggested by Dani Rodrik in his Has Globalization Gone Too Far?:

the most serious challenge for the world economy in the years ahead lies in making globalization compatible with domestic social and political stability ... in ensuring that international economic integration does not contribute to domestic social disintegration. (Rodrik 1997: 2)

The power of the state as such is increasingly seen merely as administration and less and less often as the governance of (national) spir- 
its (see Bauman 1998: 55-76; Albrow 1996: 163-183). References made to (Humboldt's) culture and (Kant's) rationality as regulatory ideas standing behind the functioning of the present institution of the university no longer ring social and political bells as they no longer seem necessary in the era of globalising capitalism: the idea of national culture ceases to be crucial for the present functioning of the state and the state as such, also out of necessity (for instance, out of fear of economic isolation) seems to be increasingly less national in the classical sense of the term. (Saskia Sassen in her book Losing Control? Sovereignty in an Age of Globalization describes the current situation brought about by globalisation as 'partial denationalizing of national territory' and as a 'partial shift of some components of state sovereignty to other institutions, from supranational entities to the global capital market' [Sassen 1996: xii]).

Thus, the raison d'être of the university as a significant partner of the nation-state exhausts itself. Andy Green makes in this context an interesting observation about modern relations between power and knowledge:

States created nations of citizens in a multitude of ways. They conscripted and disciplined them in the national defence; they registered their births, marriages and deaths; they monitored and regulated their movements across borders and their political activities; they punished and incarcerated them ... But most of all they educated them. (Green 1997: 134, emphasis mine)

The university in its traditional modern form is no longer a partner of the nation-state as it is incompatible with the perspective of global consumerism. Therefore, together with the decline of modernity as a social, political and cultural project the political and economic role of the nation-state decreases in the global circulation of capital, and the decreasing role of the state goes hand in hand with the decreasing role of its modern ideological arm - the university. ${ }^{7}$ While we can see quite easily the transformations in economy and politics, ${ }^{8}$ it is a bit more difficult to see the changes occurring at the other pole of the power/knowledge relation, that of knowledge. Power and its character get changed and therefore, out of necessity, knowledge and its character get changed. The historicity of the two projects was perhaps most fully presented in Michel Foucault's historical-philosophical accounts of modernity: the human and social sciences in their current forms appeared at the behest of power: modern states already born or about to be born. Although Foucault focused on modern criminology, 
psychology, psychiatry, medicine, identity and sexuality, perhaps similar genealogical questions could be asked about the institution of the university? (see Ball 1990)

Let me say a few words on the margins right now, as a higher education policy analyst rather than a philosopher of culture: the other side of the same coin, and a much more sociological account of the current situation of institutions of higher learning, is the following: hard times have come for higher education all over the world. It is not accidental that following the end of the Cold War, the collapse of communism, and the further spread of the free market and neoliberal economic views, public higher education institutions are under siege worldwide. Current problems with higher education are connected with much deeper problems of the public sector in general. Financing and managing higher education institutions was at the top of the agenda worldwide in the 1990s. Interestingly enough, the patterns of reform and the directions contemplated were similar in countries with different political-economic systems and different higher education traditions, not to mention different technological and civilisational advancement (Johnstone 1998: 2). No matter what fiscal prosperity we might expect - conclude numerous recent policy reports - hard times are coming for our educational institutions (see Hovey 2000; Finn 2000). Budgets are going to be squeezed; state support is declining and expected to decline further, owing to other huge social needs; and at the same time a massification and expansion of higher education is taking place amidst a growing social dissatisfaction with the public sphere in general.

Globalisation processes and fierce international competition brought back to the world agenda the issue of the role of the state in the contemporary world: as the World Bank publication The State in a Changing World put it in its opening paragraph:

Around the globe, the state is in the spotlight. Far-reaching developments in the global economy have us revisiting basic questions about government: what its role should be, what it can and cannot do, and how best to do it. (World Bank 1997: 1)

Rethinking the university today is inseparable from rethinking the state today: first, the modern university was placed by its German philosophical founders at the disposal of the nation-state, but also, second, the university is traditionally a vast consumer of public revenues. And rethinking the state goes in two parallel directions: the nation-state today and the welfare state today. Both ideas are clearly linked with the modern institution of the university, and fundamental 
reformulations of them will surely affect it. Generally, the state is increasingly seen as a 'facilitator', 'regulator', 'partner', and 'catalyst' rather than a direct provider of growth or of social services. What it means is a redefinition of the state's responsibilities towards society and high selectivity in activities supported with public funds. 'Choosing what to do and what not to do is critical', as the World Bank publication nicely phrases it - and in this context hard times are ahead for higher education worldwide. OECD's Redefining Tertiary Education speaks of a 'fundamental shift' and a 'new paradigm' of tertiary education for all, as well as about a 'historic shift' and a 'cultural change'. I fully agree with its claim that 'it is an era of searching, questioning, and at times of profound uncertainty, of numerous reforms and essays in the renewal of tertiary education' (OECD 1998: 3,37,20,15).

Thus the question about the university today cannot be answered in isolation; it goes hand in hand with questions about cultural and civilisational changes brought about by the Internet and information technology, with the issues of globalisation, the welfare- and nation-state, etc. As a result of all these changes it may happen that certain activities traditionally viewed as belonging to the state's sphere of responsibility may not be seen in this way any more. Higher education is certainly a serious issue in this context, and the general trend towards subsidising consumers rather than providers, that is to say, students rather than institutions of higher learning (or 'the client perspective' in OECD terminology), as well as a shift not only away from government but also away from higher education institutions and their faculty to their 'clients' (Johnstone 1998: 4), is symptomatic. The conclusion about higher education would be that the global direction taken by governments worldwide, with huge intellectual support provided by supranational organisations, is toward lifelong education for all, wide access with modest tuition, massive learning at more and more market-oriented, financially independent institutions of higher education. This direction is quite explicit nowadays. And the above description goes hand in hand with the power/knowledge relations between the modern nation-state and the modern university that I am analysing in this paper.

\section{III}

The question of the decline of the nation-state is of huge human, social, economic and political consequence. I have to agree with Zyg- 
munt Bauman when he says that the model of postmodernity 'cannot be grounded in the realities of the nation-state, by now clearly not a framework large enough to accommodate the decisive factors in the conduct of interaction and the dynamics of social life' (Bauman 1992: 65). But what does it mean: the decline of the nation-state? This common expression finds numerous explanations. To give several of the most recent examples: Susan Strange in her book The Retreat of the State refers to the 'reversal of the state-market balance of power' and says that the state

is undergoing a metamorphosis brought on by structural change in world society and economy ... [I]t can no longer make the exceptional claims and demands that it once did. It is becoming, once more and as in the past, just one more source of authority among several, with limited powers and resources. (Strange 1996: 4,73)

Martin Albrow goes even further when he states that

effectively the nation-state no longer contains the aspirations nor monopolises the attention of those who live on its territory. The separation of the nation-state from the social relations of its citizens is by no means complete, but it has advanced a long way.

Or, to put it in a nutshell, 'society and the nation-state have pulled apart' (Albrow 1996: 170,176). Another sociologist of globality, Ulrich Beck in his splendid What Is Globalization? describing the 'second modernity', claims that

the advent of globalization involves not only an erosion of the tasks and institutions of the state, but also a fundamental transformation of its underlying premisses. The second modernity brings into being, alongside the world society of national states, a powerful non-state world society different from previously existing forms of political legitimation, which is made up of transnational players of the most diverse kinds. (Beck 2000: 103)

Globalisation in his account brings about a society that is multidimensional, polycentric and contingent and in which the national and the transnational coexist with each other. What is at stake in the globalisation campaign is not only the fate of the nation-state: it is also political freedom, democracy and the substance of politics, for if global capitalism dissolves, the core values of the work society, 'a historical link between capitalism, welfare state and democracy will break apart' (Beck 2000: 62). Finally, in thinking about the nation- 
state today it is important to avoid the global/national duality, as Saskia Sassen keeps reminding us both in her Losing Control? Sovereignty in an Age of Globalization and in the more recent Globalization and Its Discontents: it is not simply that the national state is merely losing significance, it is not that 'what one wins, the other loses', because "the state itself has been a key agent in the implementation of global processes, and it has emerged quite altered by this participation' (Sassen 1996: 29); and it is engaged in the 'production of legality' around new forms of global economic activity (Sassen 1998: 200). In this light the alternative, 'states or markets' (see Colclough \& Manor 1991), may not be as sharp as it looks at first sight. Our thinking about the nation-state brings us to thinking about globalisation and about whether it is a social process or political rhetoric (see Scott 1997: 1), whether and to what extent it is a political rather than a merely economic project, and, last but not least, whether we regard it as still a 'choice' or already a 'reality'. ${ }^{9}$ As to the question whether the state will disappear, my answer would be: it will not, but what remains will certainly not be the state as we know it. It will no longer be a provider of public and social services and it may become much more of an arbiter between competing, mainly economic, forces, guaranteeing fair play of all participants in the economic game. What appeals to me is the frank attitude revealed by Thomas L. Friedman in his recent controversial book The Lexus and the Olive Tree:

I didn't start globalization, I can't stop it - except at a huge cost to human development - and I'm not going to waste time trying. All I want to think about is how I can get the best out of this new system, and cushion the worst, for the most people. (Friedman 1999: xviii)

I would add that the collapse of the modern institution of the university is a 'reality', to use the above dualism, and our task could be getting the best out of this new (postmodern, globalised, post-national) academe that is about to emerge.

\section{IV}

Could it be that the modern institutions of the nation-state and the university have so far remained in harmonious and fruitful equilibrium because the modern figures of power and knowledge have remained in equilibrium? Two parallel products of modernity, the nation-state and the modern university, have been in an amazing and 
long-term symbiosis until quite recently. And today, as Robert Holton in his Globalization and the Nation-State puts it: 'Individual nationstates ... are confronted not only by transnational economic power, but also, and in large measure, by transnational regulatory institutions' (Holton 1998: 80-81).

The awareness of the fact that the university invented and proposed to the world by the nineteenth century German thinkers is a culturally and historically determined product is increasingly common. Nothing determines in advance its shape, tasks or functions or the expectations directed at it and the requirements enforced on it by the culture and the society in which it is immersed. The university in its modern form is a child of modernity; it grows older together with it and is susceptible to political, economic and social transformation as much as any other (modern) institution. The tradition of twenty five centuries of Plato's Academy, or of eight centuries of the University in Bologna, seems irrelevant.

The modern university would not have been invented if Enlightenment thinkers had not been able to show, for the first time in the history of European consciousness, that the progress of knowledge and the progress of politics go hand in hand. According to Alan Bloom, Enlightenment was a brave philosophical undertaking because its aim was to restructure political and intellectual life in such a way that in its totality it should fall under the supervision of philosophy and science. Thus, higher education provided the foundations for liberal democracy and was a reservoir of its principles. But what happens, we may ask, when a traditional political architecture gets changed, silently and irresistibly, together with the processes of globalisation? What happens when political progress does not seem to be strictly connected with the progress of knowledge? What happens when knowledge in the sense of the knowledge developed at the traditional modern university, according to the best German ideals of the dyad of teaching and research, ceases to be politically crucial?

The question to be asked could be the following: what alternative universally legitimising set of ideas can be found for universities when the grand narrative within which the university was useful for the constitution of the liberal, reasonable subject of the nation-state, seems to have been rendered useless? Is it possible at all in more and more postmodern times to find such a firm (and convincing) grand narrative? The scientist - as well as the humanist, and the philosopher - has long ago ceased to be the historical or cultural hero he or she used to be in the Enlightenment, and, to an extent, in the time of Positivism. ${ }^{10}$ 
Perhaps, as the idea of 'culture' (and especially, but not exclusively, 'national' culture) ceases to be effective for the functioning of the institution of the university - the idea of culture worked out by German philosophers and accepted all over the world as a regulatory idea standing behind the functioning of the university - new ideas have to be sought. It turns out, though, that such grand ideas that would not be deprived of social reference, are very difficult, if not impossible, to find in the set of ideas we currently have at our disposal. At the same time - and that is the crucial claim I want to make in the present essay - the ruthless logic of consumerism provides us with the idea which was greeted with satisfaction by the best American universities: 'excellence in education', behind which there are the ideals of the most useful, best-selling and most rapidly attained knowledge. As numerous commentators of the phenomenon write, it is right there that the university as an institution becomes a bureaucratically-governed, consumer-oriented corporation. ${ }^{11}$ To quote just one recommendation:

The only thing that higher education has to do, it seems, is sell its goods and services in the marketplace like other businesses ... (Leslie \& Fretwell 1996:31)

From this perspective, the crucial words for the description of the university are the following: managerial, corporate, entrepreneurial, ${ }^{12}$ as well as corporatisation, marketisation and 'academic capitalism' ${ }^{13}$

Thus, national consciousness ceases to play a crucial role in the social life of present technologically advanced states, and national identity ceases to be the most important social glue of late-modern society $;{ }^{14}$ as Susan Strange notes: 'Today it is much more doubtful that the state ... can still claim a degree of loyalty from the citizen substantially greater than the loyalty given to family, to the firm, to the political party or even in some cases to the local football team' (Strange 1996: 72). The hitherto existing social task, that of taking care of the spiritual life of the inhabitants of the rational nation-state, no longer suffices for the present functioning of the institution of the university. The university, surely enough, still functions, but in an increasingly different manner: it either refers to the logic of production and consumption (of knowledge), that is to say, it sells its product with better or worse results, or it struggles violently with the state that is generally, all over the world, less and less willing to support the public university that in turn refers to its rights gained in modern culture (see Hovey 1999, Hovey 2000, Johnstone 1998). (The fact that the state, in practice rather than in theory, is less and 
less concerned about the fate of the university derives also - apart from globalisation pressures for competitiveness and cutting public expenditure - from its cold calculation which is rarely affected by a deeper consciousness of the cultural changes I am writing about here: the university is no longer a partner of the state, but becomes a petitioner, and is treated like a petitioner, a fact especially visible in Central European countries. As the editors of an important recent American book Higher Education Under Fire sadly remark: we are no longer a high priority ... [Bérubé \& Nelson 1995: 7ff]). As far as particular academic disciplines within the university are concerned, the current emphasis within the university is perhaps best described by Slaughter and Leslie in their Academic Capitalism (1997: 208): 'the center of the academy has shifted from a liberal arts core to an entrepreneurial periphery'.

The questions to be asked could be formulated in the following manner: what is the future of the university deprived of its modern culture-, state-, and nation-oriented mission? Does the university really have to drift toward the model of a better and better managed corporation, a bureaucratic structure fighting in the marketplace with other, similar, isolated bureaucratic structures in search of consumers of educational services they want to keep selling (i.e. to drift 'from the collegial academy to corporate enterprise', as Ian McNay describes the process)? Is the gaining of professional knowledge as significant as the social mission which until recently was crucial for the provision of national consciousness? What, in a social sense, would a (potential) university of mere consumers be like? ${ }^{15}$

Or, as is evident in a splendid volume Universities and Globalization, the questions could be the following: are we in danger of having at and in the university practices drawn directly from the world of business? Will the university under these circumstances be able to maintain critical judgments about society? Will scholars become entrepreneurs ('academic capitalists')? Is university activity still unique in our culture? Is globalisation a 'regime of truth' (in Foucault's sense), a new fundamentalism? Finally, is higher education merely a private commodity or is it a public good ${ }^{16}$ At the same time, a less cultural and philosophical context and a more economic and political one could be described as follows:

most Western democracies are now in the throes of a reform of their welfare state institutions. The modern university, as a significant claimant on public resources, is part of it ... the overriding influence in all countries 
is that the state can no longer afford to pay the escalating claims, especially in light of the increasing internationalization of the economy. (Melody 1997: 76)

Present questions about the university can be derived once again from 'foundational' texts of this same institution: texts by the German Idealists (this 'actual charter of the university in the classical sense', as Hermann Röhrs (1995: 18) puts it). In this context it is worthwhile to return to texts by Newman and Dewey, and more contemporaneous ones by Allan Bloom and Richard Rorty in America or by Nietzsche, Jaspers, Heidegger, Habermas, Lyotard, Derrida and Foucault in Europe. It would be interesting to study Rousseau's and Nietzsche's attacks on the institution of the university as well. For the questioning of the modern university is inseparable from a more general questioning of modernity as a large cultural, social and political project. It is only in this context, I suppose, that we can arrive at the objectives that modernity ascribed to the university, and try to reformulate them for the purposes of today's, changed and still changing world of latemodernity. It is surely possible to pretend that nothing has happened (and that nothing will happen), for higher education is crucial to the civilisational success of, for instance, young, Central European democracies at the moment of their entering the European Union. The problem is that these are merely words and no consistent vision of the university can be built on them. The state no longer sees its direct interest in more seriously financing an institution that has already lost its state- and nation-oriented role in society. ${ }^{17}$

Incidentally, to add another dimension to our discussion, the institution of the university is not the only one that is affected, or may soon be affected, by the gradual completion of the project of modernity. Another modern product, the figure of the intellectual in the form that we are familiar with from Zola to Sartre (and perhaps even to Foucault) in France, undergoes an equally radical crisis of identity. It is also the intellectual that turns out to be closely, for better and for worse, associated with modernity. ${ }^{18}$ Doubts about modernity go hand in hand with doubts about the figure of the intellectual. Therefore, incidentally, one often hears that 'the confidence of intellectuals in their own activities has been reduced and there is no one available to speak for the university' (Smith \& Webster 1997: 5). Undoubtedly, in 
this context it would be interesting to study the relations between the figure of the intellectual and the institution of the modern university - from the perspective of tasks imposed on both by the project of modernity. The history of the university and the history of the intellectual in the twentieth century are parallel. It would be interesting to see whether the causes of their contemporary completion (or perhaps only reformulation) are similar.

Generally speaking, the decline of modernity turns out to be a painful process for culture: once again it has to reformulate the aims of its social institutions and the tasks of its cultural heroes. If it is successful, the institutions and cultural heroes in question will regain their cultural vitality; if it is not, they will fall into cultural sterility. The traditional figure of the intellectual seems untenable in a more and more postmodern cultural surrounding. The modern institution of the university may face similar choices: either it is going to find a new regulative idea, or it will have to accept the rules of bureaucratic, consumer-oriented corporations, or else it may try once again to find a totally new role in culture about which little is known at the moment and which would have to be as transformative as the role originally suggested for the university by Kant, Humboldt, Fichte and Schleiermacher (the differences between them notwithstanding). ${ }^{19}$ The breakthrough in conceiving of the university two hundred years ago was an event equal in importance to the vast social and cultural transformations of that time. It is hard to tell whether there will appear new ideas about the university comparable in significance to the ideas of the German Idealists.

In this vein, we have to bear in mind that the role of the institution of the university proposed at the turn of the nineteenth century was closely connected to its context. The idea of the modern university was not born out of nowhere. It can be called the alliance of power and knowledge, following Michel Foucault; it can also be called the alliance of science and politics (the ultimate consequence of which was the relationship between American science and American politics during the Cold War, about which Noam Chomsky (1997: 171ff) has recently written). But the idea of the modern university can also be recognised as a perfect adaptation to the needs of newly born, or about to be born, nation-states, and a perfect intrusion of the sciences and humanities into the changing social surroundings.

Following this theme, one could ask about the following: what can the university as an institution propose today, in a world that is more and more disenchanted and pluralistic, cosmopolitan, multicultural 
and multiethnic? Suddenly, after two centuries of standing arm in arm with the nation-state, the modern institution of the university has to look for a new raison d'être, a new justification, a new legitimisation of its - extremely high - place in culture. Obviously, it can be said that nothing changes, for the processes I am referring to here, first, take many years, and second, do not necessarily appear everywhere, for example in Central Europe. But we do know that social evolution in Central Europe is very fast indeed and it may turn out that in a moment we will be facing similar problems to those faced by universities in Anglophone countries from New Zealand and Australia to Canada and the USA. It is a good idea, I suppose, to think about them in advance, and look for possible solutions even before the very problems are present (especially considering the influence that supranational organisations currently exert on Central European higher education reforms ${ }^{20}$ ).

\section{VI}

To return for a moment to the question of the use of the university today if it no longer provides the legitimisation to power by building national identity: perhaps the university could play an important role, for instance, in supporting (already partially forgotten) the ideals of civil society? ${ }^{21}$ The question arises, who needs these ideals? Society, surely, since, paradoxically enough, society now has no good place from which to learn them. But how to pass from national ideals to civil ideals that would in principle be deprived of merely local references? The process of the passing of American universities from the ideal of (American) culture to the ideal of a financially independent (educational) corporation - commonly referred to as their 'corporatization' (Newson 1998: 108ff) - is surely not worth being copied without further discussion of its implications. The only question is to what extent there is still any choice in our increasingly homogeneous world. If there was such a choice, and let us assume this optimistically, the university could become a centre for pluralistic, multiperspectival thought that would take care of the ideals of civil society in a more and more corporate-like world of global capital (see Soley 1995; Beck 2000; Bauman 1998).

It might be possible to escape the traps of globalisation with respect to the institution of the university if the university found some great idea (and a great narrative standing behind it) that it could see 
as its own. The idea of reason and the idea of (national) culture were such ideas, as Readings convincingly demonstrates; perhaps such an idea could become the ideal of civil society. But how are we to make these ideals not too 'grand', so that they would not be rejected together with a general postmodern rejection of the grand narratives of modernity? How are the ideals of civil society to be recontextualised so that they do not appear too modern, that is to say, too enchanted and too ideological? How are the ideals of civil society to be worked through so that they do not disappear together with the large social projects brought about by the Enlightenment and the French Revolution? If such a direction of thinking were destined to fail, what remains possible for the university is a passage to the pure logic of gains and losses, production and consumption, from which there seems to be no escape.

The university that consented to function within the framework determined purely by the logic of the (neoliberal) economy would, with the passage of time, become a mere corporation (and it would not find any consolation in the fact that it is an "educational corporation'). That would be the end of the university as a modern institution. Therefore I have to agree with Slaughter and Leslie when they say that 'higher education as an institution and faculty as its labor force face change unprecedented in this century' (Slaughter \& Leslie 1997:1). That would obviously not mean the end of the university as such: that would be merely the end of a certain way of conceiving of the university, a conception with which we have, over a period of two centuries, become familiar. The university without its state- and nation-orientation (that is, de-ideologised) seems to be forced by external circumstances to look for a new place for itself in culture, for if it does not find such a place, it will become an educational corporation tasked with training specialists fast, cheaply, and efficiently preferably very fast, very cheaply, and very efficiently.

Social and cultural changes today occur with a speed that was unimaginable a few decades ago. The world is changing faster and faster and the university has less and less influence on the direction these changes take (if it ever had any influence). It is no longer a partner of power (of the nation-state); it has become one among several budgetary items that, preferably, should be cut or reduced. One thing is certain: nothing is permanent or guaranteed in culture, neither status nor place, role or social task. This fact is well known by all those whose influence in culture has been radically reduced. Participants in the current debate about the future of the university certainly 
have to avoid a survivalist mentality; otherwise what Zygmunt Bauman says about globalisation in general - 'it is not about what we all ... wish or hope to do. It is about what is happening to us all' (Bauman 1998: 60) - will come true with respect to the globalisation of higher education in particular.

\section{VII}

Thus, the potential decline of the project of modernity and of the nation-state entails the potential decline of the institution of the modern university, requiring the latter to search for a new place in culture and new ideas organising its functioning at the moment when the harmonious cooperation of power and knowledge - or, more precisely, of the politics of the nation-state and the national consciousness provided by the university - has ended. Globalisation brings about the devalorisation of all national projects, one of them being the institution of the (nation- and state-oriented) university. If behind the university there are no longer the ideas of nation, reason and (national) culture, then either new ideas have to be discovered, or the university is doomed to surrender to the all-encompassing logic of consumerism. Within this logic the university, free from its associations with power, devoid of modern national and state missions, is merely to 'sell' its educational 'product' as a bureaucratic educational corporation. The study of the future of the institution of the university is inseparable from the study of it within the large cultural, philosophical, and political project of modernity.

To sum up, present cultural, political and economic transformations brought about by globalisation and the decline of the nationstate undermine the very foundations of the modern model of the university. It faces a radical reformulation of its ideas. There are brand new models of the functioning of the university available, recommended, suggested or imposed. For two hundred years the identity crisis of the university was not serious, but now we may be witnessing a tectonic shift in the fundamental role played so far by the nationstates that contributed to the appearance of the modern university in the form with which we are familiar. We will surely still have some universities. The point is: their future shape is forming right now. It is fascinating to see the process; it is even more useful to try to understand it; it would be most useful to try to influence it. 


\section{Acknowledgments}

I would like to acknowledge the generous support provided by the Center for Policy Studies, Central European University, in the form of an International OSI Policy Fellowship. The paper is an adapted version of the Open Lecture I delivered at the Central European University, Budapest, on March 29, 2000, in my capacity as visiting professor there.

\section{NOTES}

1. On the complicated relations between the German Humboldtian model and its American counterparts, see an already classical book by Frederick Rudolph, The American College \& University: A History, published in 1962 (new edition, Athens: University of Georgia Press, 1991) and a recent book by Christopher J. Lucas, American Higher Education: A History, New York: St. Martin's Press, 1994). See also Carl Diehl's Americans and German Scholarship 1770-1870, New Haven: Yale University Press, 1978; or Hermann Röhrs, The Classical German Concept of the University and Its Influence on Higher Education in the United States, Frankfurt am Main: Peter Lang, 1995.

2. See especially recent works by two leading British sociologists: Zygmunt Bauman and Anthony Giddens.

3. The present essay was inspired a couple of years ago by that splendid book.

4. As the above mentioned Barnet and Cavanagh say: ' ... no political ideology or economic theory has yet evolved to take account of the tectonic shift that has occurred. The modern nation-state ... looks more and more like an institution of a bygone era' (Barnet \& Cavanagh 1997:19). See also Sassen (1996), as well as, for a French perspective, Guéhenno (1995). It is Guéhenno who clearly links ' 1989 ' with the collapse of the nation-state: ' 1989 marks the twilight of a long historical era, of which the nation-state, progressively emerging from the ruins of the Roman Empire, was the culmination' (1995: xii).

5. The texts about the institution of the university written by German philosophers of the turn of the nineteenth century were gathered in the French volume Philosophies de l'Université, edited by Luc Ferry, Alain Renaut et al., Paris: Payot, 1979.

6. See the splendid English-German edition of The Conflict of the Faculties, New York: Abaris Books, 1979.

7. Andy Green asks about the role of education in a 'post-national era' and claims that according to globalisation theories the system of national education becomes 'defunct, at once irrelevant, anachronistic and impossible' (Green 1997: 3ff). 
8. As Janice Dudley claims:

The state is cast as increasingly irrelevant when confronted by the 'reality' of ungovernable international/global market forces. Nation-states are essentially ineffective in the face of global market forces, so that the era of the powerful nation-state would appear effectively to be over. National economic management, and national political and social policies are becoming increasingly irrelevant. International markets and international capital markets operate outside of the control of national governments ... The state is reduced to the role of the 'night watchmen' of classical liberalism - maintaining law and order, protecting the sanctity of contract, and providing only the level of welfare necessary to protect property and facilitate the free operation of capitalist markets. (Newson \& Currie 1998: 27)

9. See the exchange between Thomas L. Friedman and Ignacio Ramonet in 'Foreign Policy', Fall 1999, which shows the difference between French and American attitudes toward globalisation.

10. Among philosophers, this decline in the social role of these figures is most widely shown by Richard Rorty. Let me suggest here my commentary on this attitude in 'After Philosophy: The Novelist as Cultural Hero of Modernity?' in Theoria: A Journal of Social and Political Theory, no. 92, December 1998.

11. The late Bill Readings writes precisely about the 'University of Excellence'. From a more practical perspective, two other works are more significant: Wise Moves in Hard Times: Creating and Managing Resilient Colleges and Universities by David W. Leslie and E.K. Fretwell Jr., San Francisco: Jossey-Bass, 1996, and Reinventing the University: Managing and Financing Institutions of Higher Education, edited by Sandra L. Johnson and Sean C. Rush, New York: John Wiley \& Sons, 1995, which do not leave a shadow of a doubt about the general direction in which the university as an institution moves. Its aim is 'providing an attractive product at a fair price - giving society value for its money' (Leslie \& Fretwell 1996: 26). In the other book one can find such statements as the following: 'Higher education will never be the same. Political and corporate America have already responded by fundamentally restructuring the way they operate' (Johnson \& Rush 1995: 22). The time has come for the universities to respond ...

12. It is important to note the two significant books that have appeared within a decade: Janice Newson and Howard Buchbinder, The University Means Business: Universities, Corporations and Academic Work, Toronto: Garamond Press, 1988; and Jan Currie and Janice Newson (eds), Universities and Globalization: Critical Perspectives, London: Sage, 1998. Both present precise reports and detailed interpretations by sociologists and political scientists of the phenomena occurring at the anglophone universities. They show the way the ideology of free market enters the university in the form of practices drawn directly from the corporate world (high-level management, rectors as CEOs, nominated rather than elected deans, accountability, privatisation, performance indicators, etc.).

13. 'Academic capitalism' is the term coined by Sheila Slaughter and Larry L. Leslie. I fully agree with the diagnosis they present:

globalization of the political economy at the end of the twentieth century is destabilizing patterns of university professional work developed over the past hundred years. Globalisation is creating new structures, incentives, and rewards for some aspects of academic careers and is simultaneously institut- 
ing constraints and disincentives for other aspects of careers. (Slaughter \& Leslie 1997: 1)

14. The modern institution of the university in Central Europe does not fall under the evolution described here for obvious historical reasons. But it may face, or already does face, the same challenges globalisation and its ideology bring about.

15. See especially discussions about the 'unique' place of higher education in society contrasted with its current 'survivalist' mood in The Postmodern University? Contested Visions of Higher Education in Society, edited by Anthony Smith and Frank Webster, London: Open University Press, 1997. The only option still open for the university to defend itself today is to stress the unique nature of the university experience as such which, to tell the truth, is not enough.

16. All these questions underlie this extremely useful collective volume.

17. I am leaving aside in this text fascinating, although ideological, discussions that have taken place in the USA in the 1990s about the university. They assumed the perspective of current struggles for the intellectual hegemony between conservatives and the Left, and from that perspective either attacked or defended the university. From a philosophical point of view they are not important, although from the point of view of American culture and society they proved crucial for the process of gradual change of attitude of the American public to the institution of the university. Let me mention here three of them: Martin Anderson, Impostors in the Temple, New York: Simon and Schuster, 1992; Roger Kimball, Tenured Radicals: How Politics Has Corrupted Our Higher Education, New York: Harper and Row, 1992; and Dinesh D'Souza, Illiberal Education: The Politics of Race and Sex on Campus, New York: The Free Press, 1991. Philosophically, more important seemed to be Bruce Wilshire's The Moral Collapse of the University, New York: SUNY, 1990, and, especially, Allan Bloom's best-selling The Closing of the American Mind, published in 1987.

18. I was writing about this process in a book The Dilemmas of Identity: the SelfImage of the Philosopher in Postwar French Thought (in Polish) or in such texts as e.g. 'Zygmunt Bauman and the Question of the Intellectual in Postmodernity', Berkeley: Center for Western European Studies, Working Paper Series no. 22, 1997, and 'Between the Community and the Text (French Philosophy, Politics and the Figure of the Intellectual - from Sartre to Foucault)', Trames. A Journal of the Humanities and Social Sciences, Tallin: Academy of Sciences Press, no. 2, vol. 2, 1998.

19. Let us remember what was the situation of the university before German ideas came into use. As Björn Wittrock says, 'there can be little doubt that radical German philosophy helped resurrect the very notion of a university at a time when the university in Europe had been more threatened than perhaps at any time before or afterwards' (Wittrock 1993: 314).

20. What is especially interesting is the comparison between the attitude of the World Bank, OECD, and UNESCO toward higher education in the 21st century and the actions to be taken to get out of the current general crisis. See in particular four books by OECD: Universities Under Scrutiny, Education and the Economy in a Changing Society, Financing Higher Education: Current Patterns, and, especially, Redefining Tertiary Education (Paris: OECD - 1987, 1989, 1990, 1998, respectively). See also the World Bank's Higher Education: The Lessons of Experience, Washington: Author, 1995, and the Proceedings of the UNESCO 1998 World Conference on Higher Education. See also selected World Bank 
policy papers, such as (for example) Michael Gibbons' 'Higher Education Relevance in the 21st Century', Elaine El-Khawas' 'Quality Assurance in Higher Education: Recent Progress; Challenges Ahead' or D. Bruce Johnstone's 'The Financing and Management of Higher Education: A Status Report on Worldwide Reforms' prepared for the Paris conference (available on-line).

21. It is very interesting to read together in this context two texts by Stanley N. Katz: 'Can Liberal Education Cope?' (an address from 1997) and 'The Idea of Civil Society' (an address from 1998), both available from his Princeton website.

\section{REFERENCES}

Albrow, Martin. 1996. The Global Age. State and Society Beyond Modernity. Blackwell.

Allègre, Claude. 1993. L'Âge des savoirs: pour une renaissance de l'université. Gallimard.

Ball, Stephen J. (ed.). 1990. Foucault and Education: Disciplines and Knowledge. Routledge.

Barnet, Richard J. \& Cavanagh, John. 1997. Global Dreams. Imperial Corporations and the New World Order. Simon and Schuster.

Barzun, Jacques. 1993. The American University: How It Runs, Where It is Going. University of Chicago Press.

Bauman, Zygmunt. 1992. Intimations of Postmodernity. Routledge. 1998. Globalization: The Human Consequences. Polity Press.

Beck, Ulrich. 2000. What Is Globalization? (transl. by P. Camiller). Polity Press.

Bender, Thomas (ed.). 1998. The University and the City: From Medieval Origin to the Present. OUP.

Bérubé, Michael \& Nelson, Cary (eds). 1995. Higher Education Under Fire. Routledge.

Blackwell, Albert. 1991. Friedrich Schleiermacher and the Founding of the University in Berlin. Mellen Press.

Bowen, Howard \& Schuster, Jack. 1986. American Professors: A National Resource Imperiled. OUP.

Chomsky, Noam (ed.). 1997. The Cold War and the University. Toward an Intellectual History of the Postwar Years. New Press.

Colclough, Christopher \& Manor, James (eds). 1991. States or Markets? Neo-liberalism and the Development Policy Debate. Clarendon Press.

Currie, Jan \& Newson, Janice (eds). 1998. Universities and Globalization:

Critical Perspectives. London: Sage. 
Ferry, Luc et Renaut, Alain (eds). 1979. Philosophies de l'Université. Paris: Payot.

Finn Jr., Chester E. 2000. 'A Different Future for Higher Education?'. Fordham Foundation.

Friedman, Thomas L. 1999. The Lexus and the Olive Tree. Farrar, Straus \& Giroux.

Giddens, Anthony. 1990. The Consequences of Modernity. Polity Press.

Green, Andy. 1997. Education, Globalization and the Nation State.

Macmillan.

Guéhenno, Jean-Marie. 1995. The End of the Nation-State (transl. by

Victoria Elliott). University of Minnesota Press.

Guiomar, Yves. 1990. La Nation entre l'histoire et la raison. La

Découverte.

Holton, Robert J. 1998. Globalization and the Nation-State. St. Martin's

Press.

Hovey, Harold A. 2000. 'State Shortfalls Projected Despite Current Fiscal

Prosperity'. The National Center for Public Policy and Higher

Education.

. 1999. State Spending for Higher Education in the Next Decade.

The Battle to Sustain Current Support. The National Center for Public

Policy and Higher Education.

Humboldt, Wilhelm von. 1979. 'Über die innere und äussere Organisation der höheren wissenschaftlichen Anstalten in Berlin', in Luc Ferry, J.-P.

Pesron \& Alain Renaut (eds), Philosophies de l'Université. L'idéalisme allemand et la question de l'Université. Payot.

Johnson, Sandra L. \& Rush. Sean C. (eds). 1995. Reinventing the

University: Managing and Financing Institutions of Higher Education.

New York: John Wiley \& Sons.

Johnstone, D. Bruce. 1998. 'The Financing and Management of Higher

Education: A Status Report on Worldwide Reforms'. UNESCO World

Conference on Higher Education. [Available on-line]

Kant, Immanuel. 1970. Political Writings. CUP. . 1979. The Conflict of the Faculties. New York: Abaris Books.

Keller, George. 1983. Academic Strategy. Johns Hopkins University Press.

Kerr, Clark. 1994. Troubled Times for American Higher Education: The 1990s and Beyond. SUNY Press.

Kwiek, Marek. 1999. The Dilemmas of Identity: the Self-Image of the Philosopher in Postwar French Thought. Adam Mickiewicz University Press (in Polish).

1998. 'After Philosophy: The Novelist as Cultural Hero of

Modernity?', Theoria: A Journal of Social and Political Theory, no. 92, December 1998. 1996. Rorty's Elective Affinities. The New Pragmatism and Postmodern Thought. Adam Mickiewicz University Press, 1996 (in English). 
Leslie, David W. and Fretwell, E.K. Jr. 1996. Wise Moves in Hard Times. Creating and Managing Resilient Colleges and Universities. San Francisco: Jossey-Bass.

Lucas, Christopher J. 1996. American Higher Education: A History. New York: St. Martin's Press.

Lyotard, Jean-François. 1984. The Postmodern Condition. A Report on Knowledge. Manchester University Press.

Marsden, George M. 1994. The Soul of the American University. OUP. McClelland, Charles E. 1980. State, Society, and University in Germany, 1700-1914. Harvard University Press.

McNay, Ian. 1995. 'From the Collegial Academy to Corporate Enterprise: The Changing Cultures of Universities', in Tom Schuller (ed.), The Changing University? Open University Press.

Melody, William. 1997. 'Universities and Public Policy', in Anthony Smith \& Frank Webster (eds), The Postmodern University? Contested Visions of Higher Education in Society. London: Open University Press.

Newson, Janice. 1998. 'The Corporate-Linked University: From Social Project to Market Force', Canadian Journal of Communication, vol. 23.

Newson, Janice \& Buchbinder, Howard. 1988. The University Means

Business: Universities, Corporations and Academic Work. Toronto: Garamond Press.

OECD. 1990. Financing Higher Education. Current Patterns. Author. 1987. Universities Under Scrutiny. Author. 1989. Education and the Economy in a Changing Society.

Author. 1998. Redefining Tertiary Education. Author.

Readings, Bill. 1996. The University in Ruins. Harvard University Press.

Renaut, Alain. 1995. Les Révolutions de l'université. Essai sur l amodernisation de la culture. Calmann-Lévy.

Richardson, Herbert (ed.). 1984. Friedrich Schleiermacher and the Founding of the University of Berlin. Edwin Mellen Press.

Rodrik, Dani. 1997. Has Globalization Gone Too Far? Institute for International Economics.

Röhrs, Hermann. 1995. The Classical German Concept of the University and Its Influence on Higher Education in the United States. Frankfurt am Main: Peter Lang.

Rothblatt, Sheldon. 1997. The Modern University and Its Discontents. CUP.

Rothblatt, Sheldon \& Wittrock, Björn. 1993. The European and American University Since 1800. CUP.

Rudolph, Frederick. 1991. The American College and University: A History. Athens: University of Georgia Press.

Sassen, Saskia. 1996. Losing Control? Sovereignty in an Age of Globalization. Columbia University Press. 1998. Globalization and Its Discontents. New Press. 
Schelling, Friedrich W.J. 1963. On University Studies. Ohio University Press.

Schleiermacher's Writings on Academia. 1994. Edwin Mellen Press.

Scott, Alan (ed.). 1997. The Limits of Globalization. Cases and Arguments. Routledge.

Slaughter, Sheila \& Leslie, Larry L. 1997. Academic Capitalism: Politics, Policies, and the Entrepreneurial University. Johns Hopkins University Press.

Smith, Anthony \& Webster, Frank (eds). 1997. The Postmodern University?

Contested Visions of Higher Education in Society. London: Open

University Press.

Soley, Lawrence C. 1995. Leasing the Ivory Tower: The Corporate Takeover of Academia. South End.

Spybey, Tony. 1996. Globalization and World Society. Polity Press.

Strange, Susan. 1996. The Retreat of the State: the Diffusion of Power in the World Economy. CUP.

Thompson, Jo Ann Gerdemann. 1985. The Modern Idea of the University. Peter Lang.

Trow, Martin A. \& Thorsten, Nyborn (eds). 1991. University and Society: Essays on the Social Role of Research and Higher Education. Jessica Kingsley.

Waters, Malcolm. 1995. Globalization. Routledge.

Wilshire, Bruce. 1990. The Moral Collapse of the University. New York: SUNY Press.

Wittrock, Björn. 1993. 'The Modern University: the Three Transformations', in Sheldon Rothblatt \& Björn Wittrock (eds), The European and American University since 1800. CUP.

World Bank. 1994. Higher Education: The Lessons of Experience. Author. 1997. The State in a Changing World. Author.

World Conference on Higher Education (UNESCO). 1998. Higher Education in the 21st Century. Vision and Action. Paris. [Proceedings available on-line] 